\title{
Kontrola operacyjna w informacyjnym systemie zarządzania zgrzewaniem doczołowym szyn realizowana w czasie rzeczywistym
}

\begin{abstract}
Kontrola operacyjna jakości zgrzewania szyn jest zasadniczym elementem kontroli procesu całego procesu technologicznego produkcji szyn. W praktyce do tego celu stosowane sa systemy działajace $w$ czasie rzeczywistym. W artykule zaproponowano nowa metodę, która stosuje logikę rozmyta do analizowania danych pochodzacych z testów mechanicznych połaczeń oraz inspekcji ultradźwiękowej połaczeń.
\end{abstract}

Słowa kluczowe: logika rozmyta, spawanie, kontrola operacyjna

\section{WPROWADZENIE}

Monitorowanie procesów produkcji składa się z kontroli wkładu, kontroli operacyjnej i kontroli przyjęcia. Kontrola wkładu to kontrola produktu, który dociera do konsumenta i jest przewidziany do użycia w procesie produkcji. Materiały wykorzystane przy produkcji muszą być sprawdzone. Kontrola operacyjna to kontrola produktu lub procesu, który odbywa się podczas realizacji określonych działań lub po ich zakończeniu. Kontrola przyjęcia jest kontrolą produktu finalnego. W jej wyniku zapada decyzja o zgodności produktu z normami i wymaganiami użytkowymi oraz o dostarczeniu produktu do konsumenta. Wyniki kontroli przyjęcia służą identyfikacji tych wad produktu, które nie zostały zidentyfikowane w trakcie kontroli operacyjnej oraz wprowadzeniu ewentualnych koniecznych zmian.

Zgrzewanie doczołowe iskrowe jest procesem o wielu zmiennych, w którym można wskazać różne fazy i zmiany napięcia, prądu, przemieszczenia, prędkości, oporu i energii (rys. 1). Aby uzyskać maksi- mum informacji o naturze i przebiegu procesu zgrzewania doczołowego iskrowego oraz by poznać jego cechy, przeprowadzono ciągłą rejestrację tych parametrów na etapie opracowania technologii zgrzewania doczołowego iskrowego [1]. Informacja ta użyta została przez konstruktorów do udoskonalenia procesu zgrzewania, jednak nie posłużyła jako źródło oceny jakości zgodnie z dokumentami normatywnymi.

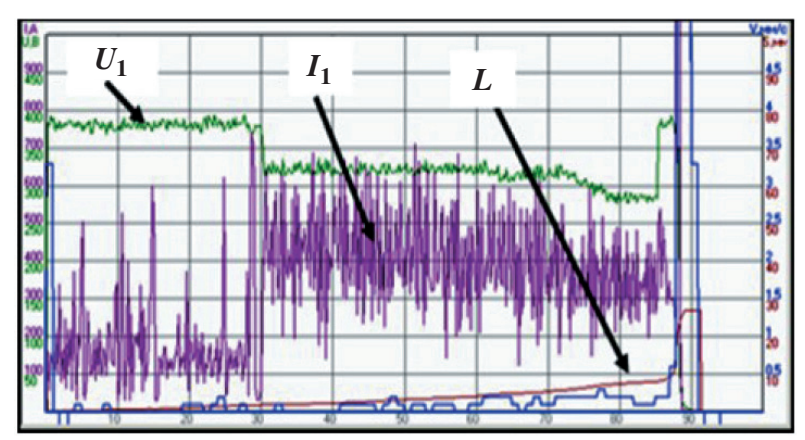

Rys. 1. Proces zapisywania procesu zgrzewania doczotowego iskrowego szyn na maszynie K1000. $U_{1} i I_{1}-$ napięcie i prąd zgrzewania na wejściu transformatora, L - liczba przemieszczeń części zgrzewanych (próbka stopionego metalu i spęczanie) 
W wyniku eksperymentów zidentyfikowano zależności jakościowe poprzez zmiany niektórych parametrów zgrzewania, jak też zbadano wpływ tych parametrów na zmianę struktury spawów. W wyniku tych działań informacja o zmianie jakichkolwiek parametrów może być użyta do oceny ilościowej tego wpływu. Jakość spawów określona jest tolerowanymi odstępstwami głównych parametrów, zapisanymi w warunkach technicznych produktów spawanych (tab. 1). Można było zatem przeprowadzić kontrolę działania procesu rejestracji oraz porównanie tych parametrów w czasie rzeczywistym w celu natychmiastowego określenia parametrów wyjściowych warunków tolerancji, a także zmniejszyć prawdopodobieństwo uzyskania zgrzewu o niskiej jakości [1].

\section{Tabela 1}

Tolerowane odstępstwa od podstawowych parametrów zgrzewania doczołowego iskrowego na maszynach mobilnych, takich jak K900, K920, K922 (szyny typu P65, UIC60) oraz na maszynie stacjonarnej K1000 (szyny typu P50, P65, P75, UIC60)

\begin{tabular}{|l|c|}
\hline \multicolumn{1}{|c|}{ Parametry zgrzewania } & Wartości parametrów \\
\hline Císnienie spęczania [MPa] & $9-12$ \\
\hline Prędkość spęczania [mm/s] & nie mniej niż 20/30 \\
\hline Prędkość topnienia [mm/s] & $0,065-0,20 / 0,07-0,20$ \\
\hline $\begin{array}{l}\text { Prędkość w chwili zakończenia } \\
\text { topnienia [mm/s] }\end{array}$ & $0,7-2,5$ \\
\hline $\begin{array}{l}\text { Napięcie wejściowe } \\
\text { transformatora zgrzewającego [V]: } \\
\text { - uzwojenie pierwotne } \\
\text { - uzwojenie wtórne }\end{array}$ & $355-440$ \\
\hline Naddatek topnienia [mm] & $250-360$ \\
\hline Naddatek spęczania [mm] & $9-18$ \\
\hline
\end{tabular}

\section{KONTROLA POŁACZEŃ}

Kontrola przyjęcia spawów opiera się na inspekcji ultradźwiękowej oraz testach mechanicznych próbek szyn, regularnie w trakcie procesu zgrzewania. Kontroli dokonuje się na zgodność z warunkami technicznymi (obciążenie stopki szyny co najmniej $1400 \mathrm{kN}$ przy odchyleniu co najmniej $30 \mathrm{~mm}$ według norm ukraińskich oraz odpowiednio $1600 \mathrm{kN}$ i $20 \mathrm{~mm}$ według norm Unii Europejskiej). Testy akceptacyjne mogą być również użyte to skorygowania ustalonych wartości tolerancji.
Główną wadą takiego rodzaju kontroli wartości tolerancji jest to, że nie bierze ona pod uwagę następujących czynników:

- istotnej roli wpływu parametrów pojedynczych i ich kombinacji w celu oszacowania jakości spawu,

- rozmieszczenia parametrów procesu w zakresie wartości tolerancji,

- zatarcia granic tolerancji.

Biorąc to pod uwagę, w celu oceny jakości spawów (test wytrzymałości spawów oraz wartości zgięcia), opracowano algorytm sterowania na podstawie logiki rozmytej. Z powodu złożoności procesu zgrzewania doczołowego iskrowego nie można było stworzyć modelu analitycznego, statystycznego czy innego modelu numerycznego. Ocena jakości spawu, z określonym poziomem prawdopodobieństwa, oparta jest na regułach logicznych zawartych w studium na temat technologicznych właściwości zgrzewania doczołowego iskrowego.

Oto niektóre z tych reguł [1,2]:

- im wyższa samoregulacja, tym wyższa stabilność topnienia;

- im wyższa stabilność topnienia, tym niższa intensywność niszczenia styków spawanych;

- im niższy opór zwarciowy maszyny spawalniczej $Z_{s c}$, tym wyższa samoregulacja (wyższa stabilność topnienia) i może dojść do zmniejszenia napięcia topnienia $U_{m e}$.

Pole temperatury w zgrzewanym produkcie określić można za pomocą współczynnika wydatkowanej energii $Q$ oraz wartości próbki stopionego metalu $L$ (tab. 2).

$\mathrm{Na}$ tej podstawie i na podstawie podobnych reguł opracowano oparte na logice rozmytej zasady oceny jakości połączeń spawanych.

Aby uwzględnić granice rozmycia dopuszczalnych odchyleń konwersji wartości parametrów procesu, użyto ich zgodnie z wartościami tolerancji specyfikacji w liczbie bezwymiarowej - stopień jej zgodności według specyfikacji parametrów w warunkach technicznych. Funkcje przekształceń, które mogą przybierać różne kształty, przedstawiono w formie trapezu (rys. 2). Tak więc w środku tej tolerancji $X_{a v} \pm \Delta X$, gdzie $X_{a v}-$ wartość średnia oraz $\Delta X=1 / 6\left(X_{\max }-X_{\min }\right)$, funkcja przynależności specyfikacji parametru jest równa 1 , a następnie, w zakresie tolerancji, zmniejsza się liniowo do zera. Zależności logiczne od efektu jakościowego parametrów procesu zgrzewania oporowego doczołowego opracowano na podstawie wniosków technologicznych, które biorą pod uwagę zarówno względny wpływ na proces, jak i lokalizację parametrów w strefie tolerancji. 
Tabela 2

Ocena pola temperatury w zależności od błędów odtwarzania danej energii $Q$ oraz wartości próbki topionego metalu $L, T F$ - pola temperatury (oh - przegrzanie, lh - niedogrzanie)

\begin{tabular}{|c|c|c|c|c|c|}
\hline$T F$ & $\begin{array}{c}\text { Duży bląd ujemny } \\
L\end{array}$ & $\begin{array}{l}\text { Mały bląd } \\
\text { ujemny } L\end{array}$ & $\begin{array}{c}\text { Wartość } \\
\text { nominalna } L\end{array}$ & $\begin{array}{l}\text { Maly bląd } \\
\text { dodatni } L\end{array}$ & $\begin{array}{l}\text { Duży bląd } \\
\text { dodatni } L\end{array}$ \\
\hline Duży błąd ujemny $Q$ & złe $T F$ & $\begin{array}{c}\text { zle } T F \\
\text { (lh) }\end{array}$ & $\begin{array}{c}\text { złe } T F \\
\text { (lh) }\end{array}$ & $\begin{array}{c}\text { złe } T F \\
\text { (lh) }\end{array}$ & $\begin{array}{c}\text { zle } T F \\
\text { (lh) }\end{array}$ \\
\hline Mały błąd ujemny $Q$ & $\begin{array}{c}\text { złe } T F \\
\text { (oh) }\end{array}$ & normalne $T F$ & $\begin{array}{c}\text { złe } T F \\
\text { (lh) }\end{array}$ & $\begin{array}{c}\text { złe } T F \\
\text { (lh) }\end{array}$ & $\begin{array}{l}\text { złe } T F \\
\text { (lh) }\end{array}$ \\
\hline Wartość normalna $Q$ & $\begin{array}{c}\text { złe } T F \\
\text { (oh) }\end{array}$ & $\begin{array}{c}\text { złe } T F \\
\text { (oh) }\end{array}$ & normalne $T F$ & $\begin{array}{l}\text { złe } T F \\
\text { (lh) }\end{array}$ & $\begin{array}{l}\text { złe } T F \\
\text { (lh) }\end{array}$ \\
\hline Mały błąd dodatni $Q$ & $\begin{array}{c}\text { złe } T F \\
\text { (oh) }\end{array}$ & $\begin{array}{c}\text { złe } T F \\
\text { (oh) }\end{array}$ & $\begin{array}{c}\text { złe } T F \\
\text { (oh) }\end{array}$ & normalne $T F$ & $\begin{array}{l}\text { złe } T F \\
\text { (lh) }\end{array}$ \\
\hline Duży błąd dodatni $Q$ & $\begin{array}{c}\text { złe } T F \\
\text { (oh) }\end{array}$ & $\begin{array}{l}\text { złe } T F \\
\text { (oh) }\end{array}$ & $\begin{array}{l}\text { złe } T F \\
\text { (oh) }\end{array}$ & $\begin{array}{c}\text { złe } T F \\
\text { (oh) }\end{array}$ & normalne $T F$ \\
\hline
\end{tabular}
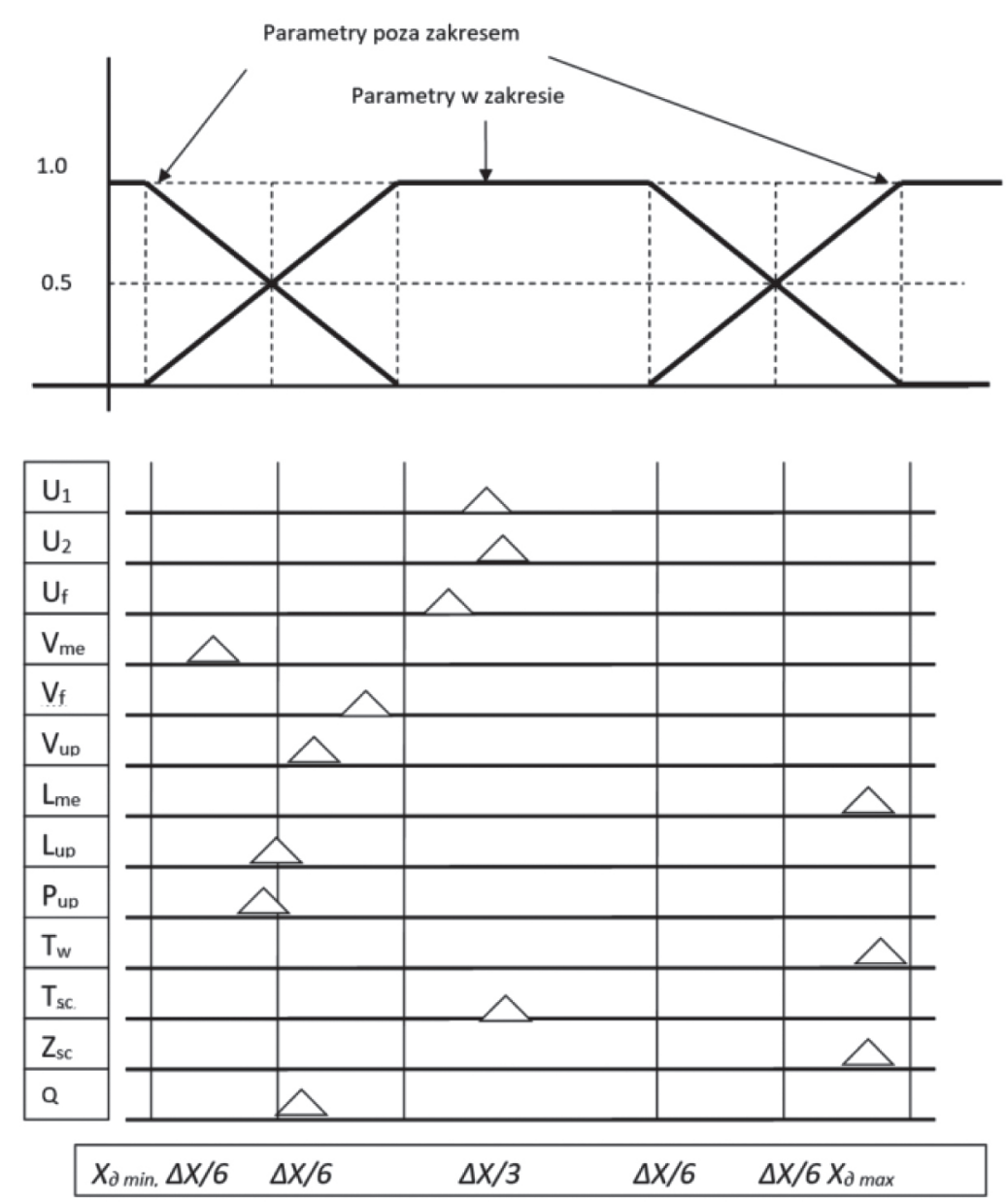

Rys. 2. Funkcja konwersji rozmytej zgrzewania oporowego czołowego w celu kontroli jakości połączeń spawanych

Ocena jakości zgrzewania przeprowadzana jest więc w wyniku analizy parametrów na trzech etapach procesu: topnienie próbek metalu - utworzenie pola temperatury na końcach zgrzewanych produktów, końcowy etap topnienia próbek metalu - utworzenie środowiska ochronnego w przerwie iskrowej oraz spęcznienie - utworzenie związków chemicznych w fazie stałej. Wynik określany jest przez stopień wiarygodności opcji dopasowania na tych etapach specyfikacji tolerancji oraz, co za tym idzie, prawdopodobieństwa uzyskania styku spawanego odpowiadającego warunkom technicznym.

W następnym etapie te wyrażenia logiczne zostały przetworzone za pomocą znanych reguł na formę 
dogodną do implementacji na komputerze. Oprócz wyjaśnienia kwestii tolerancji rozwijany algorytm sterowania może być aktualizowany zgodnie z wynikami porównania jego oceny dotyczącej akceptacji danych przez adaptację algorytmów i sieci neuronowych [4-7].

\section{SYSTEM ZARZADZZANIA}

Informacje na temat parametrów procesu oraz opinia o ich zgodności z warunkami technicznymi, w formie protokołu, stanowia kluczowy zestaw danych o procesie zgrzewania. Dane te sa przechowywane przez cały czas realizacji procesu zgrzewania na liniach kolejowych i zawieraja duże ilości informacji. Informacje te, razem z certyfikatem zgodności produktu, moga być używane do wykrywania zakłóceń procesu zgrzewania, lecz nie są mierzalne za pomocą metod bezpośrednich. Takie metody przetwarzania danych, nazywane eksploracją danych, używane są do wykrywania wcześniej nieznanych danych (Wikipedia: https://pl.wikipedia.org/wiki/Eksploracja_danych).

Użycie znanych metod przetwarzania danych statystycznych na temat styków, zbieranych przez konkretne okresy na tej samej maszynie, w tym samym zakładzie zgrzewającym szyny lub w całej branży przemysłowej pomagają zoptymalizować warunki obsługi maszyn spawalniczych oraz zarządzanie procesem produkcji szyn zgrzewanych.

W tym celu w Instytucie Paton we współpracy z Instytutem Technik Innowacyjnych EMAG z Katowic opracowano dwupoziomowy system zarządzania informacją (rys. 3). Na niższym poziomie cyfrowy sys- tem sterowania używa tradycyjnej kontroli jakości połączeń spawanych w celu natychmiastowej reakcji na zespolenie i zapobiega jego dalszemu rozpowszechnianiu.

Następnie informacje o stykach spawanych przekazywane są z maszyny zgrzewającej w fabryce na wyższy poziom - do centrum diagnostycznego. Centrum to przeprowadza statystyczne przetwarzanie protokołów ze zgrzewania szyn, tak aby wykryć zakłócenia, które trudno kontrolować za pomocą bezpośrednich pomiarów. Na przykład słaba realizacja działań pomocniczych $\mathrm{w}$ zakresie przygotowania szyn przed procesem zgrzewania, odchylenia od fizykochemicznych własności szyn metalowych, słabe przygotowanie technologiczne personelu obsługi technicznej, złe warunki produkcji.

Oprócz bezpośredniej kontroli cyfrowej procesu zgrzewania, istniejące lokalne systemy sterowania oferują następujące funkcje:

- przewidywanie jakości połączeń spawanych dla bardziej zaawansowanych algorytmów z możliwością użycia usług profesjonalistów w szczególnych przypadkach;

- monitorowanie warunków technicznych sprzętu zgrzewającego oraz tworzenie rekomendacji i planowania w zakresie utrzymania systemu;

- identyfikacja i rozpoznanie sytuacji alarmowych $\mathrm{w}$ celu przeprowadzenia natychmiastowej interwencji w procesie;

- identyfikacja odchyleń systemowych i trendów w parametrach procesu zgrzewania, które mogą prowadzić do pogorszenia jakości spawów, tworzenie rekomendacji do dostosowania parametrów zgrzewania.

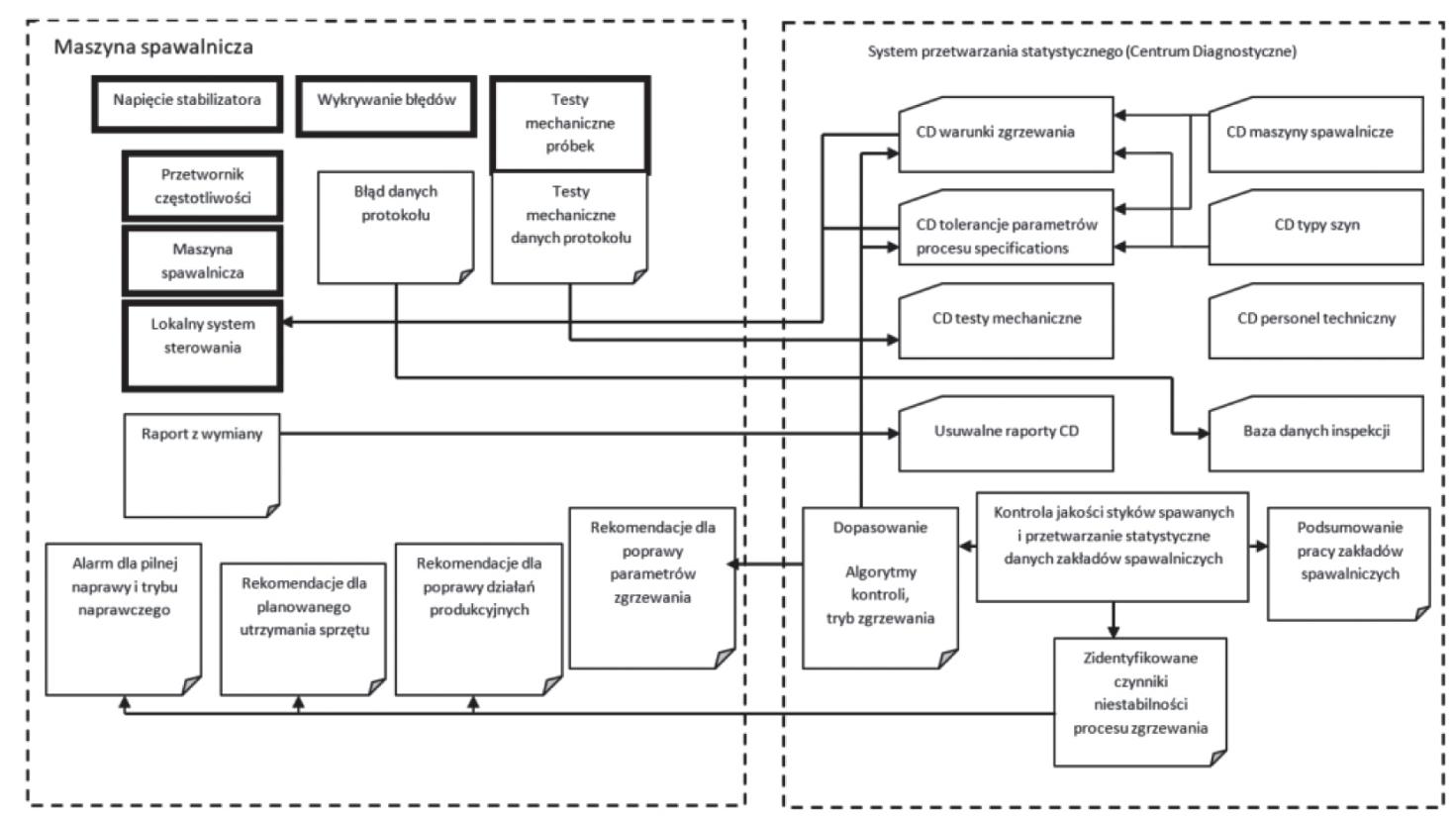

Rys. 3. Schemat blokowy dwupoziomowego systemu zarzadzania informacja 
W przypadku zgrzewania doczołowego iskrowego na maszynach stacjonarnych i przenośnych następujące czynniki mogą powodować odchylenia w procesie produkcji i tym samym naruszenie jakości połączeń spawanych $[1,2]$ :

1) słaba realizacja działań pomocniczych przeprowadzanych na szynach przed rozpoczęciem zgrzewania takich jak: przygotowanie końców, oczyszczanie powierzchni szyn, działania w zakresie zasilania prądem oraz postępowanie ze spawami po zgrzewaniu - obróbka powierzchni szyn w trakcie stępiania ostrych krawędzi;

2) pogorszenie stanu technicznego sprzętu zgrzewającego, na przykład wzrost oporu w maszynie spawalniczej;

3) wady metalu, z którego odlana jest szyna;

4) słaba praktyka technologiczna spawacza (ułożenie szyn przed zgrzewaniem);

5) niezadowalające warunki produkcji, na przykład niepożądane zmiany w napięciu zasilania;

6) niekorzystny układ parametrów procesu, nawet jeżeli parametry są $\mathrm{w}$ granicach tolerancji, na przykład obniżenie napięcia zasilania i zwiększenie oporu maszyny spawalniczej.

W celu identyfikacji opisanych zakłóceń następuje przetwarzanie protokołów dotyczących spawów za pomocą metod statystycznych oraz ich grupowanie według odpowiednich cech (tab. 3).
Podczas zgrzewania, w czasie rzeczywistym generowane są następujące informacje (rys. 4):

1) Wskaźnik jakości połączenia spawanego (prawdopodobieństwo zgodności z wymaganiami specyfikacji) obliczany jest po zgrzaniu połączenia na zmierzonych wartościach procesu zgrzewania przy użyciu algorytmu sterującego opartego na logice rozmytej [4-7]. Dane dotyczące numeru maszyny spawalniczej, nazwiska spawacza, inżyniera oraz członków zespołu do działań pomocniczych (przygotowanie szyn przed zgrzewaniem i obróbka styków spawanych po zgrzewaniu) zostały odpowiednio zgrupowane.

2) Pęknięcia, brak połączenia, matowe plamy itp. sprawdzane są za pomocą inspekcji ultradźwiękowej dla każdego styku spawanego. Dane te są zapisywane w bazie danych inspekcji. Wizualnie sprawdza się również jakość obróbki styku po stępieniu ostrych krawędzi. Informacja o wyżej wymienionych defektach oraz o błędnym interfejsie przetwarzania jest natychmiast dostępna dla spawaczy i brygadzisty. Wadliwy styk jest wycinany. Funkcje te są realizowane poza kontrolą systemu. Dane z inspekcji wprowadzane są ręcznie.

3) Na początku, w środku i na zakończenie dnia pracy przeprowadza się testy mechaniczne wybranych zespawanych szyn. Dane testowe odchylenia $L_{d e}$ i wytrzymałości $F_{b}$ są porównywane z określonymi

Tabela 3

Identyfikacja przyczyn naruszeń w procesie zgrzewania doczołowego iskrowego szyn

\begin{tabular}{|c|c|c|c|c|c|}
\hline Lp. & $\begin{array}{c}\text { Przyczyna naruszenia procesu } \\
\text { zgrzewania doczołowego } \\
\text { iskrowego szyn }\end{array}$ & $\begin{array}{l}\text { Identyfikacja } \\
\text { parametrów }\end{array}$ & $\begin{array}{l}\text { Wielkość } \\
\text { próbki }\end{array}$ & $\begin{array}{c}\text { Grupy } \\
\text { parametrów }\end{array}$ & $\begin{array}{c}\text { Efekty } \\
\text { parametryczne }\end{array}$ \\
\hline 1 & $\begin{array}{c}\text { działania pomocnicze: } \\
\text { przygotowawcze przed } \\
\text { zgrzewaniem oraz po } \\
\text { zakończeniu procesu zgrzewania }\end{array}$ & $\begin{array}{c}Z_{s c}, \text { przetwarzanie } \\
\text { danych } \\
\text { wizualnych } \\
\text { po zgrzewaniu }\end{array}$ & $1-2$ dni robocze & $\begin{array}{c}\text { nazwisko } \\
\text { kierownika + nazwa } \\
\text { zgrzewarki }\end{array}$ & metody i sprzęt \\
\hline 2 & $\begin{array}{c}\text { stan techniczny sprzętu } \\
\text { zgrzewającego }\end{array}$ & $\begin{array}{c}T_{w}, U_{1}, U_{2}, V_{m e}, V_{f}, \\
V_{u p}, L_{o}, L_{u p}, Z_{s c} \\
\end{array}$ & $1 / 3-1$ miesiąc & numer maszyny & $\begin{array}{l}\text { utrzymanie, } \\
\text { naprawa }\end{array}$ \\
\hline 3 & $\begin{array}{l}\text { właściwości fizykochemiczne } \\
\text { szyn metalowych }\end{array}$ & $\begin{array}{c}L_{d e}, F_{b}, \text { inspekcja } \\
\text { danych }\end{array}$ & $\begin{array}{c}\text { natychmiast } \\
\text { po wykryciu lub } \\
1 \text { dzień roboczy } \\
\end{array}$ & $\begin{array}{l}\text { numer partii, znak } \\
\text { szyny, numer } \\
\text { maszyny }\end{array}$ & $\begin{array}{l}\text { korekta trybu } \\
\text { zgrzewania }\end{array}$ \\
\hline 4 & działania techniczne spawaczy & $\begin{array}{l}T_{w}, T \text { pomiędzy } \\
\text { zgrzewaniem, } Z_{s c}, \\
\text { opóźnienie }\end{array}$ & $\begin{array}{c}\text { natychmiast } \\
\text { po wykryciu lub } \\
1 \text { dzień roboczy } \\
\end{array}$ & nazwisko spawacza & $\begin{array}{l}\text { metody (instrukcje } \\
\text { produkcyjne) }\end{array}$ \\
\hline 5 & $\begin{array}{c}\text { kontrola procesowa zgrzewanych } \\
\text { próbek i inspekcja } \\
\text { ultradźwiękowa }\end{array}$ & $\begin{array}{c}L_{d e}, F_{b}, \text { dane } \\
\text { inspekcji } \\
\text { ultradźwiękowej } \\
\end{array}$ & 1 dzień roboczy & $\begin{array}{l}\text { nazwisko spawacza } \\
\text { nazwisko radiografa }\end{array}$ & metody i sprzęt \\
\hline 6 & warunki produkcji & $U_{1}, U_{2}, V_{m e}, V_{f}, V_{u p}$ & 1-2 miesiące & zakład spawalniczy & $\begin{array}{c}\text { stabilizacja } U_{p s} \\
\text { lub } T_{\text {oil }} \\
\end{array}$ \\
\hline 7 & $\begin{array}{l}\text { niepożądana kombinacja } \\
\text { parametrów procesu }\end{array}$ & $\begin{array}{l}\text { kontrola rozmyta } \\
\text { i monitoring }\end{array}$ & $\begin{array}{c}\text { natychmiast } \\
\text { po wykryciu lub } \\
1 \text { dzień roboczy }\end{array}$ & numer spawu & $\begin{array}{l}\text { korekta trybu } \\
\text { zgrzewania }\end{array}$ \\
\hline
\end{tabular}


z góry wartościami. Jeżeli uzyskane wartości sa niższe niż te określone z góry, zgrzewa się i testuje dodatkowe próbki, tak aby zidentyfikować autentyczność nieakceptowanego odstępstwa. Gdy nieakceptowane odstępstwo zostaje potwierdzone, następuje dopasowanie procesu zgrzewania. Uzyskane dane używane są do przystosowania wzorcowej kontroli jakości zgrzewania.

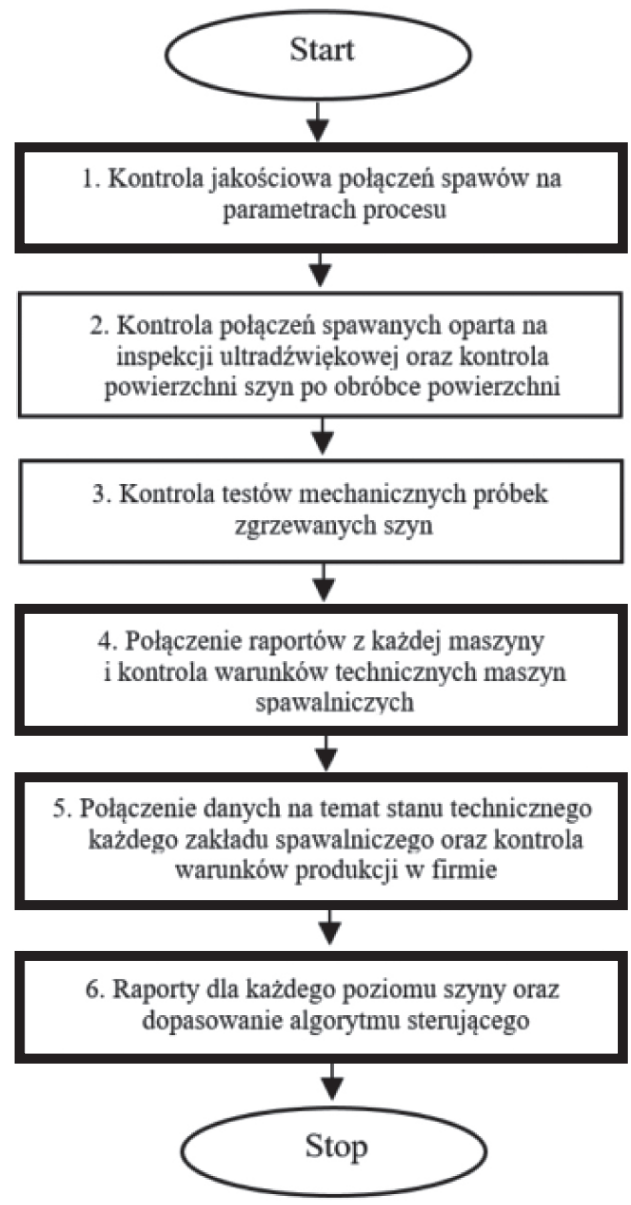

Rys. 4. Algorytm sterowania procesem zgrzewania szyn.

Działania $w$ wyttuszczonych polach

odbywaja się $w$ trybie automatycznym

W trybie offline generowane są następujące informacje.

1) Aby sprawdzić stan techniczny maszyny spawalniczej, dane z takiego samego typu szyn, zgrzewanych na tej samej maszynie, uporządkowane są według warunków technicznych maszyny (w formie protokołu). Czas reakcji i odpowiednio czas średni, mogą mieć znaczenie - od jednego do kilku dni roboczych. Oczywiście informacja na temat napraw poawaryjnych dostarczana jest bezzwłocznie.

Aby kontrolować warunki produkcji, dokonuje się oceny statystycznej zgrzewania na tym samym typie maszyny i w tej samej fabryce, a dane umieszcza się według określonego porządku. Stabilność napięcia zasilania określana jest przez napięcie $U_{1}, U_{2}$. Stabilność napędu hydraulicznego, związanego z temperaturą otoczenia i jej wpływem na płyn hydrauliczny, określona jest prędkościami $V_{m e}, V_{f}, V_{u p}$. Porównanie tych szacowanych wartości w różnych zakładach spawalniczych może posłużyć jako podstawa decyzji o udoskonaleniu warunków produkcji.

Średnie i skuteczne wartości parametrów zgrzewania zostały użyte $\mathrm{w}$ analizie statystycznej rozkładu wartości losowych parametrów procesu zgrzewania. Aby porównać różne parametry, wartości te były następnie przedstawione w jednostkach względnych, tzw. współczynniku dokładności $K_{a}$ oraz odniesienia $K_{r}[3]$ :

$$
K_{a}=6 \cdot S / \delta ; \quad K_{r}=\left(X_{a}-X_{o}\right) / \delta
$$

gdzie:

$S, X_{a}-$ RMS i średnie rozkładu parametrów procesu zgrzewania,

$\delta$ - tolerancja ustawień,

$X_{o}$ - środek tolerancji lub określona wartość.

Aby przeanalizować wariancję, należy wziąć pod uwagę, że niektóre $\mathrm{z}$ monitorowanych parametrów (np. $\left.L_{m e}, U_{1}, U_{2}, U_{3}, P_{o}, T_{u p I}\right)$ występują bezpośrednio w systemie zarządzania i błędy związane są z działaniem sprzętu oraz szczególnie z działaniem systemów sterowania.

Inne parametry $\left(V_{m e}, T_{w}, V_{f}, V_{u p}\right)$ określane są pośrednio. Błędy tych parametrów związane są zarówno ze stanem sprzętu spawalniczego, jak i z przebiegiem procesu.

Na przykład system weźmie pod uwagę dane ze wskaźnikiem dokładności $K_{a}$ z dwunastu maszyn spawających w czterech zakładach spawalniczych, z około trzydziestu tysięcy styków spawanych.

Pośrednie ustawianie wartości parametrów (rys. 6) pokazuje, że w przypadku trzech urządzeń $(10,11,12)$ zachodzi istotna różnica w kontekście czasu zgrzewania. Te maszyny zaliczają się do tzw. zgrzewarek i spodziewane jest przedstawienie przez nie całkowitego odchylenia w charakterystyce zgrzewania. Dodatkowa analiza przeprowadzona wprost na stanowisku wykazała różnice pomiędzy różnymi technologiami przygotowania końców szyn spawanych wcześniej przed zgrzewaniem w porównaniu z użyciem do tego innych zgrzewarek. 


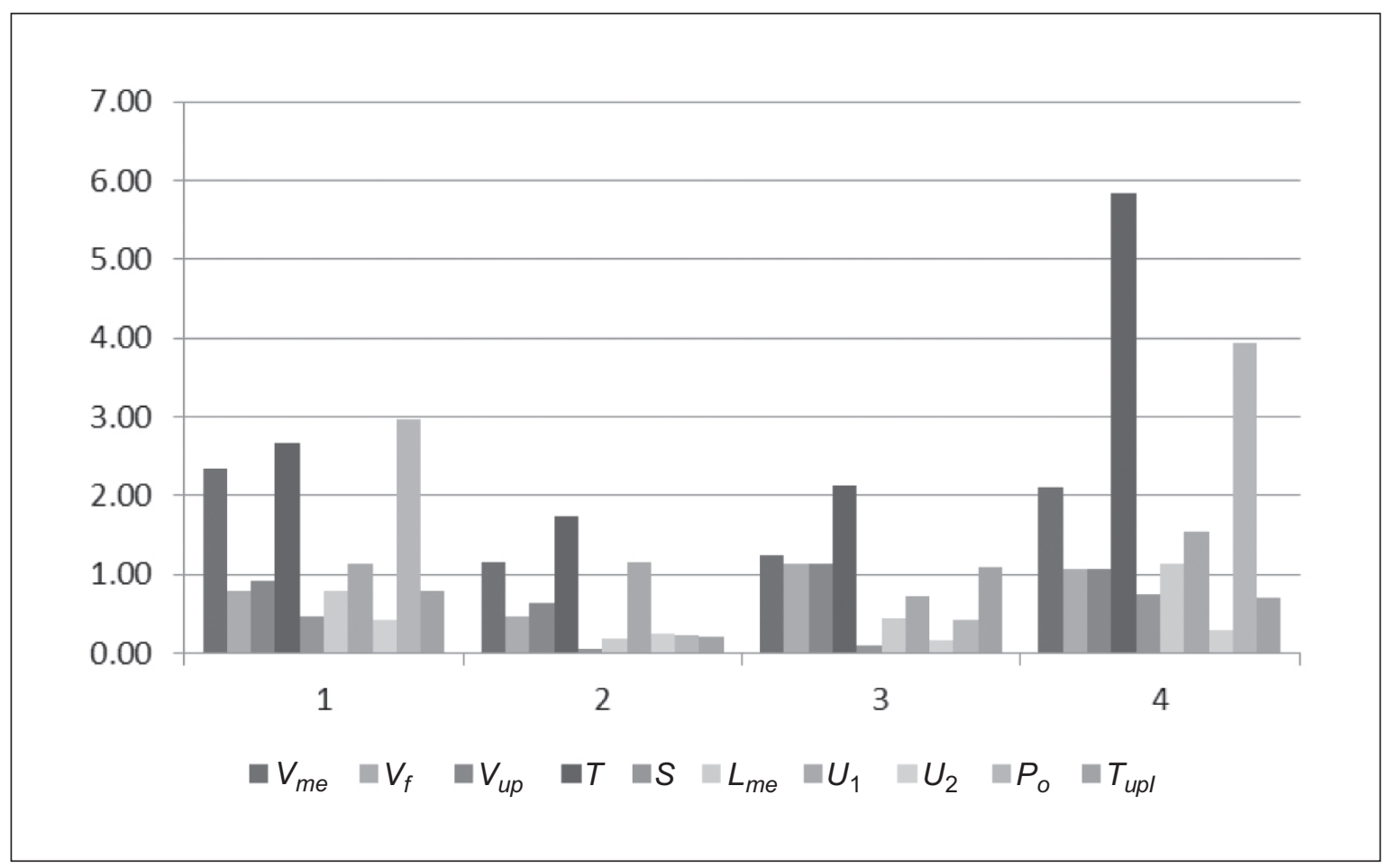

Rys. 5. Wskaźniki dokładności $K_{a}$ parametrów $V_{m e}, V_{f}, V_{u p}, T_{w}$ zgrupowane według maszyn

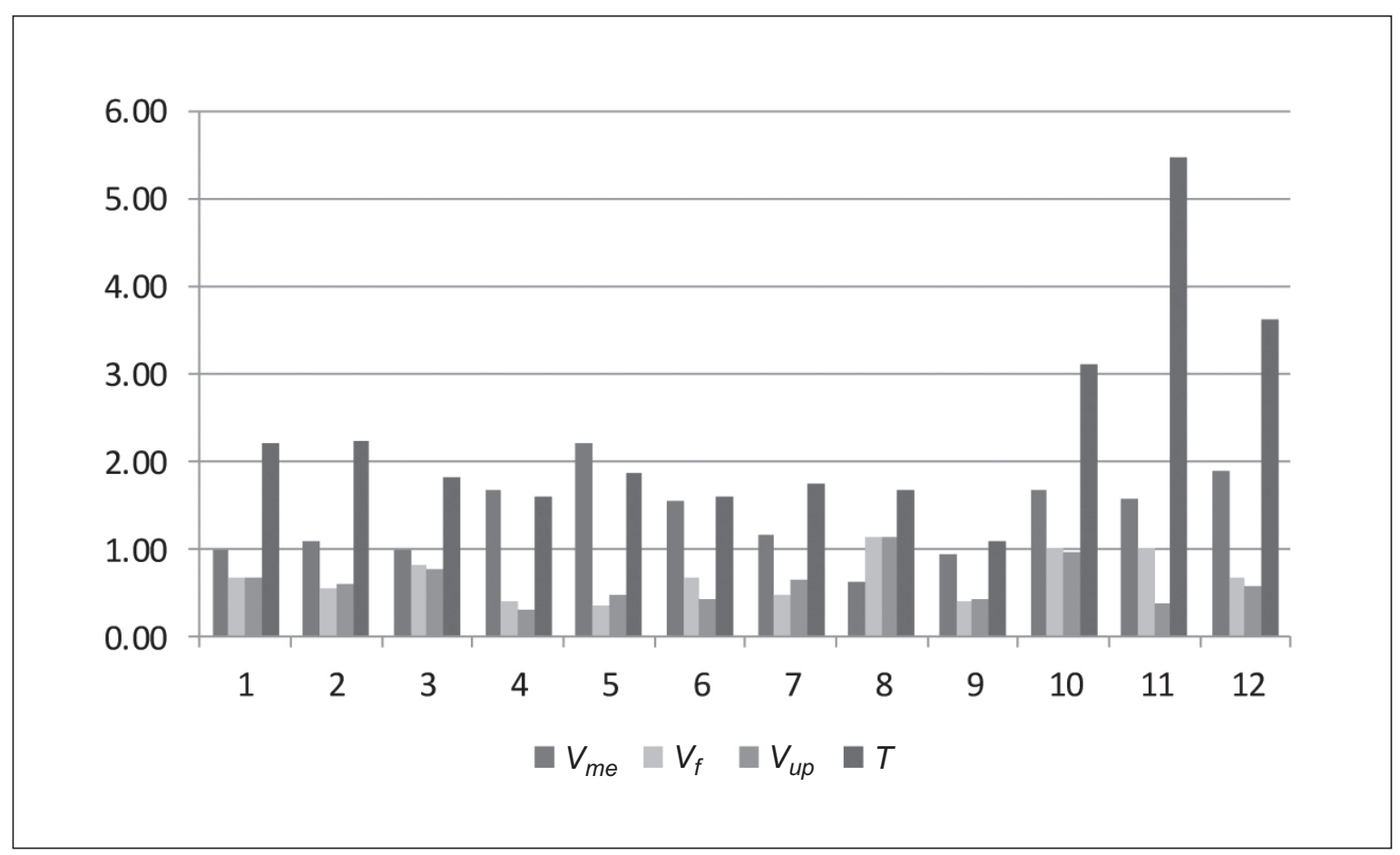

Rys. 6. Wskaźniki doktadności $K_{a}$ parametrów, zgrupowane według zgrzewarek

Wartości współczynnika $K_{a}$ dla parametrów zgrupowanych według zgrzewarek pokazują, że stacje hydrauliki w różnych zgrzewarkach (parametr $P o$ ) różnią się pod względem warunków technicznych i wymagana jest ich dodatkowa weryfikacja (rys. 6).
Oprócz kwestii technicznych algorytm zawiera kwestie organizacyjne związane $\mathrm{z}$ produkcją torów zgrzewanych. Musi być zaktualizowany nie tylko na eksperymentalnym systemie zarządzania, lecz przede wszystkim skorygowany w zakresie urządzeń serwisujących tory. 


\section{PODSUMOWANIE}

Kontrola jakości połączeń zgrzewanych oparta jest na kontroli operacyjnej, inspekcji ultradźwiękowej i testach mechanicznych próbek technologicznych.

Logika rozmyta jest podstawą do udoskonalenia niezawodności kontroli operacyjnej jako głównego środka do zapobiegania połączeniom $\mathrm{w}$ algorytmie sterującym w czasie rzeczywistym. Algorytm sterujący logiki rozmytej ustalany jest na podstawie testów mechanicznych połączeń i inspekcji ultradźwiękowej.

Opracowano dwupoziomowy system zarządzania informacją oraz przeprowadzono analizę statystyczną kontroli jakości połączeń zgrzewanych. Wyniki pokazały nowe możliwości w zakresie podwyższenia stabilności połączeń spawanych.

\section{Literatura}

[1] Jacenko S.I.: Kontaktnaja stykowaja swarka optawlenijem, Naukowa dumka, Kijew 1992.

[2] Gielman A.S.: Osnowy swarkidawlenijem, Maszynostrojenije, Moskwa 1970.

[3] Pustylnik Je.I.: Statisticzeskije mietody analiza iobrabotki nabludienij, Nauka, Moskwa 1968.

[4] Krugłow W.W., Dli M.I.: Intietlektualnyje informacyonnyje sistiemy: kompjutiernaja poddierżka sistiem nieczetkoj togiki i nieczetkogo wywoda, Fizmatlit, Moskwa 2002.
[5] Terano T., Asai K., Sueno M.: Applied Fuzzy Systems, AP Proffesional, London 1994.

[6] Kosko B.: Fuzzy Engineering, Prentice-Hall, Upper Saddle River 1997.

[7] Wang L.X.: A course in fuzzy systems and control. Prentice-Hall, Upper Saddle River 1997.

[8] Wojtas P., Kozłowski A.: Innowacyjne rozwiazania CNP EMAG, Sympozjum SEMAG: „Elektroenergetyka i automatyka w przemyśle wydobywczym”, Szklarska Poręba 2013.

SERGEI IVANOWICH KUCHUK-YATSENKO PIOTR MIKHAILOVICH RUDENKO VALERY SEMIONOVICH GAVRYSH ALEXANDR VLADIMIROVICH DIDKOVSKY VALENTINA IVANOVNA SHVETS EVGENI VALENTINOVICH ANTIPIN

The E. O. Paton Electric Welding Institute of the NAS of Ukraine, ul. Kazimir Malevich 11, 03680 Kijów, Ukraina office@paton.kiev.ua

dr inż. PIOTR WOJTAS KZESO MACHINERY sp. $z$ o.o. ul. Karoliny 4, 40-186 Katowice piotr.wojtas@kzeso.pl

dr inż. ARTUR KOZŁOWSKI Instytut Technik Innowacyjnych EMAG ul. Leopolda 31, 40-189 Katowice A.Kozłowski@ibemag.pl 